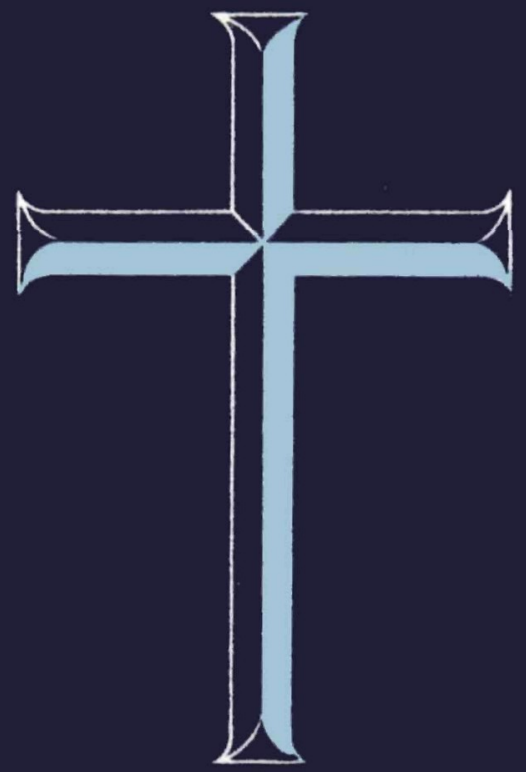

\title{
SCOTTISH JOURNAL
}
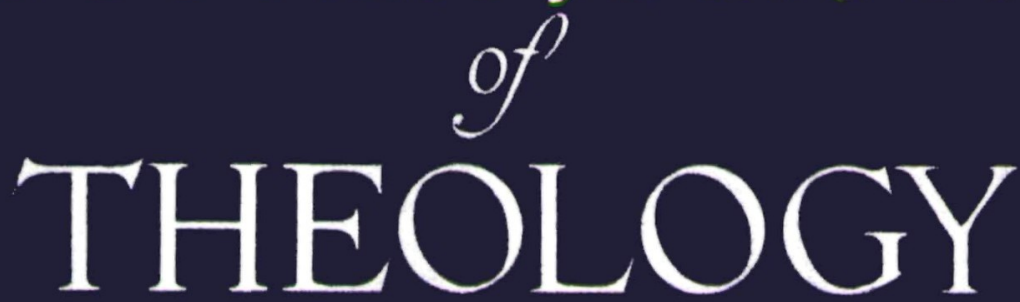


\section{ANGLICAN LITURGIES of the I th and I8th Centuries}

\section{W. JARDINE GRISBROOKE}

\section{Published for the Alcuin Club}

This book contains the texts of 12 Anglican Communion Offices, 1637-1764, an important period for both historian and liturgist. Only two of these texts have hitherto been conveniently available to the student. Historical, theological and liturgical commentary on the texts is provided.

\section{THE BELIEF OF GHRISTENDOM}

\section{J. BURNABY}

I7s. 6d. net

Professor Burnaby writes for the many who today, while attracted towards Christian faith, find difficulty in Christian belief as expressed in the Creed. He writes without assuming knowledge of technical terms, and his book will help many to understand how the Creed safeguards the Faith.

\section{TOWARDS THE CENTRE}

\section{CHARLES JEFFRIES}

45. 6d.

'A layman's brilliant treatise on union.... It would be hard to overpraise Sir Charles' masterly epitome of the course of the movement towards Christian unity and the impartiality of his estimate of how it stands today. His book is a splendid statement of that minimum knowledge and understanding lacking which no one can contribute responsibly to the debate.'

Glasgow Herald

\section{CONSUMMATUM EST}

\section{A. CORELL}

25s. net

'It is a study of eschatology in relation to the doctrine of the Church in St. John's Gospel. Few words nowadays are more abused than "eschatology" and it adjective. It is no small merit in this writer that he preserves their strict meaning, together with their background and present relevance.'

Manchester Guardian 


\section{THEOLOGY IN CONFLICT}

\section{Gustaf Wingren}

An invaluable aid in the understanding of the far-reaching implications of the ideas of Barth, Bultmann and Nygren, this book concentrates on the important relationship between the law and the gospel. Gustaf Wingren reveals what he believes to be the basic flaws in the assumptions of these great theologians.

I6s. net

\section{ELIJAH AND ELISHA}

\section{Ronald S. Wallace}

'Mr Wallace writes lucidly and with real spiritual insight. Listening to such expositions a congregation could not but grow in knowledge and understanding of the Faith they profess. It is a volume to be commended not only to the laity, but to ministers, for it is a fine example of expository preaching.'-The Scotsman

\section{I6s. net}

\section{CHRIST IN OUR PLACE}

\section{Paul van Buren}

A study of the substitutionary character of Calvin's doctrine of reconciliation. ' . . a good book and well deserves the praise with which Karl Barth recommends it in a foreword. Not only is it the first English book on Calvin's doctrine of the atonement, but it really penetrates into its subject and reaches the heart of the matter.'

ros. 6d. net 


\section{THE NATURE AND AUTHORITY OF THE BIBLE

\author{
by RAYMOND ABBA
}

'The plan and content which Professor Abba has adopted are unusual in a book on this theme, and valuable. First we have an outline of the Bible as a whole, arranged under five periods. Then follow chapters on special topics such as Revelation through History, Myth, Legend and History, Miracles and finally The Word of God.... The book should be available to all serious teachers of divinity, to training college lecturers and to students - not less to people in university departments of education.'

-Religion in Education

'In closing the book one has the feeling of having consulted a library, amid which none the less the author's opinions are clearly and forcibly expressed.... The book will prove of very great value to preachers, students, and the lay reader.' -Expository Times

'A balanced judgment on a difficult problem is found in every chapter of Mr Abba's attractive study ... the theological student will find here a condensed library of theology.... Mr Abba is particularly helpful in his discussion of myth, legend and history.'

-Church Times

218. net

From all good booksellers

JAMES CLARKE \& CO. LTD., 33 STORE ST., LONDON, W.C.x.

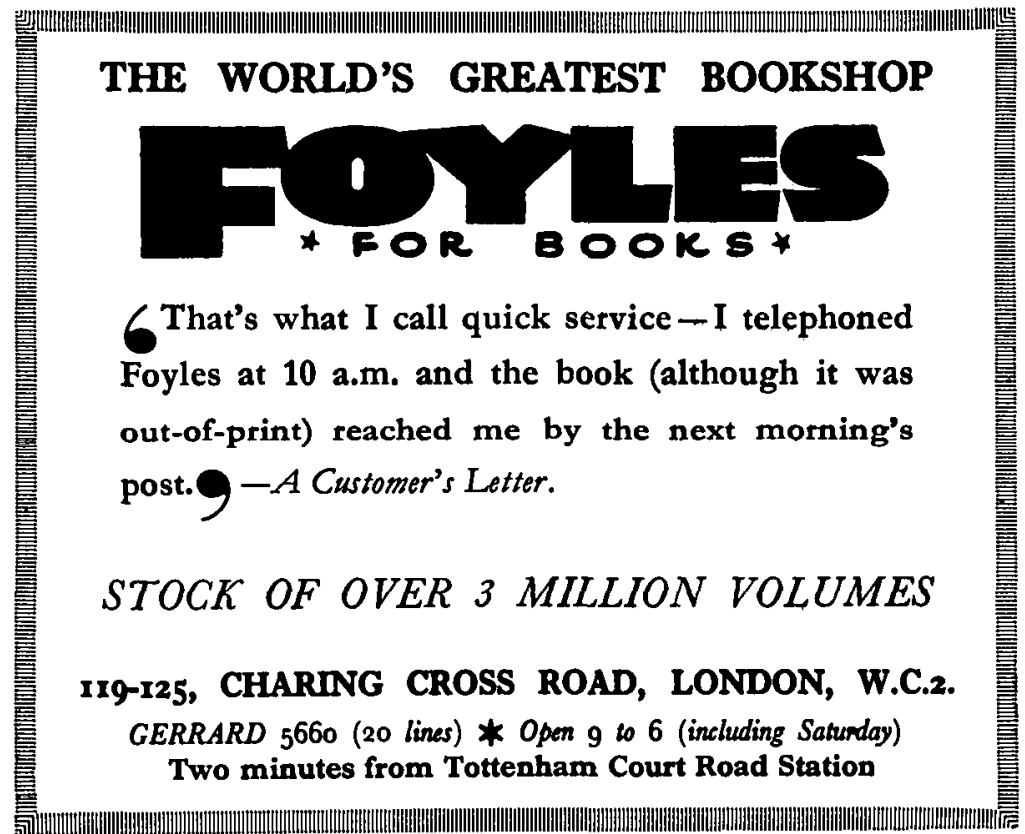




\section{SCOTTISH JOURNAL OF THEOLOGY OCCASIONAL PAPERS}

General Editors: T. F. Torrance and J. K. S. Reid

No. 1 A BIBLICAL APPROACH TO THE DOCTRINE OF THE TRINITY

by G. A. F. Knight 6s, net

No. 2 ESCHATOLOGY

by William Manson, G. W. H. Lampe, T. F. Torrance and W. A. Whitehouse 6s. net

No. 3 ROYAL PRIESTHOOD

by T. F. Torrance 9s. net

No. 4 THE BIBLICAL DOCTRINE OF THE MINISTRY

by J. K. S. Reid 5s. net

No. 5 CHRIST AND ADAM

by Karl Barth 6s. net

No. 6 THE HOLY SPIRIT AND ESCHATOLOGY IN PAUL

by Neill Q. Hamilton 8s. 6d. net

No. 7 THE APOSTOLIC MINISTRY

by A. T. A. Ehrhardt 8s. $6 d$. net 


\section{SCOTTISH JOURNAL of}

\section{THEOLOGY}

Vol. 12, No. 1

March 1959

EDITORS:

Rev. Professor T. F. TORRANCE

Rev. Professor J. K. S. REID

OLIVER \& BOYD LTD.

EDINBURGH : TWEEDDALE COURT

LONDON: 39A WELBECK STREET, W.I. 


\section{SCOTTISH JOURNAL OF THEOLOGY}

\section{Published Quarterly}

\section{Editors:}

Rev. Prof. T. F. Torrance, M.B.E., D.D., D.Theol., 2I South Oswald Road, Edinburgh, 9 (Telephone 46114)

Rev. Prof. J. K. S. ReId, D.D., 44 Headingley Mount, Leeds, 6 (Telephone ${ }^{66853}$ )

\section{Consulting Editors:}

Rev. Principal J. H. S. Burleioh, D.D., B.Litt. Chairman of Directors

Rev. Prof. David Cairns, D.D.

Rev. Prop. N. W. Porteous, D.D.

Rev, Prof, A. M. Hunter, Ph.D., D.Phil., D.D.

\section{Directors :}

The above-named together with

Rev. Prof. E. P. Dickie, M.C., D.D.

Rev. J. Heron, B.D., S.T.M.

Rev. Stewart Mechie, D.D.

Rev. J. A. MaFADDEN, B.D.

Rev. J. W. Stevenson, M.A.

Rev. J. B. Torrance, B.D.

Rev. R. S. Wallace, M.A., B.Sc., Ph.D.

Rev. T. M. Murchison, M.A., Secretary

CONTRIBUTIONS are invited from members of all branches of the Christian Church.

EDITORIAL CORRESPONDENCE-MSS and Books for review should be sent to one of the Editors.

BUSINESS CORRESPONDENCE should be sent to the Registered Office.

PRICE: Six Shillings and Sixpence (U.S.A. and CANADA \$ 1.00) per copy, post free.

ANNUAL SUBSCRIPTION: Twenty-four Shillings, post free. (U.S.A. and and CANADA $\$ 4.00)$

PUBLISHED BY OLIVER AND BOYD FOR SCOTTISH JOURNAL OP THEOLOGY LTD.

Registered Office : TWEEDDALE COURT, EDINBURGH, I 


\section{CONTENTS}

ANalogy, by the Rev. Professor John McIntyre, M.A., B.D., D.Litt., Edinburgh

PAGE

The Church and Tradition in the Pre-Nicene Fathers, by the Rev. R. P. C. Hanson, D.D., Nottingham

APtism and Evangelism, by the Rev. Professor Markus Barth, Dr Theol., Chicago

The Ecumenical Contribution of the Russian Orthodox Church, by the Rev. D.Dr. Professor Edmund Schlink, D.D., Heidelberg

Deuteronomy and the Prophetic Attitude to Sacrifice, by the Rev. Professor Robert Dobbie, Ph.D., Toronto

68

Book Reviews:

The Lambeth Conference-1958, by the Rev. Dr George S. Gunn, Edinburgh

Augustus Muir: John White, C.H., D.D., LL.D., by the Rev. R. Stuart Louden, Edinburgh

D. M. MacKinnon: A Study in Ethical Theory, by the Rev. Professor R. D. MacLennan, Kintail

George S. Hendry: The Holy Spirit in Christian Theology, by the Rev. A. Raymond George, Leeds

L. Malevez: The Christian Message and Myth, by the Rev. Dr John Macquarrie, Glasgow

L. Goppelt: Christentum und Judentum im ersten und zweiten Jahrhundert, by the Rev. Dr R. McL. Wilson, St. Andrews

G. D. Kilpatrick (ed.): $H K A I N H \triangle I A \Theta H K H$ by the Rev. Dr Ian A. Moir, Balquhidder

F. L. Cross (ed.): Studies in the Fourth Gospel, by the Rev. Professor James S. Stewart, Edinburgh

Joachim Beckmann: Quellen zur Geschichte des christl. Gottesdienstes, by the Rev. Professor T. F. Torrance, Edinburgh

Paul F. Palmer (ed.): Sacraments and Worship; M. F. Toal (ed.): The Sunday Sermons of the Great Fathers, by the Rev. Professor T. F. Torrance, Edinburgh

W. A. Visser 't Hooft: Rembrandt and the Gospel, by Maurice de Saumerez, Leeds 


\section{IN THIS ISSUE}

Articles on Analogy

Tradition

Baptism

the Russian Orthodox Church

The Biblical Study is on Sacrifice in the OT

Among books reviewed are:

the Report of the Lambeth Conference

John White's Biography

and works on Ethical Theory

the Holy Spirit

Bultmann

the Fourth Gospel

Liturgical Sources 